\title{
WHAT CHINESE WORKERS VALUE: AN ANALYSIS OF JOB SATISFACTION, JOB EXPECTATIONS, AND LABOUR TURNOVER IN CHINA
}

\author{
Peng Nie, Lanlin Ding, Alfonso Sousa-Poza*
}

\begin{abstract}
This study uses data from the 2012 China Labour-Force Dynamics Survey and 2010-2012 China Family Panel Studies to investigate job satisfaction and job expectations, as well as the association between job satisfaction and job turnover by gender among employees aged 16-65. We find not only that job satisfaction levels are relatively low, with only $46 \%$ of workers explicitly satisfied, but also that worker expectations differ significantly from what their jobs actually provide. In particular, many jobs are less interesting than expected, which prevents workers from realizing their perceived potential. This expectation gap is thus a strong determinant of job satisfaction. Men and women have similar levels of job satisfaction, yet based on observables, one would expect women's job satisfaction to be lower than it actually is, thereby lending support to the gender-job-satisfaction paradox encountered in Western studies. In contrast to Western research, we find no link between job satisfaction and job change, an observation we attribute to China's unique Confucianbased work ethic.
\end{abstract}

Keywords: job satisfaction, gender, labour turnover, China

JEL Classification: J16, J17, J20

* $\quad$ Peng Nie, Xi'an Jiaotong University, School of Economics and Finance, Xi'an, China;

University of Hohenheim, Institute for Health Care \& Public Management, Stuttgart, Germany

(Peng_Nie@uni-hohenheim.de);

Lanlin Ding, Xi'an Jiaotong University, School of Economics and Finance, Xi'an, China

(dinglanlin@stu.xjtu.edu.cn);

Alfonso Sousa-Poza, University of Hohenheim, Institute for Health Care \& Public Management, Stuttgart, Germany; IZA, Bonn, Germany (alfonso.sousa-poza@uni-hohenheim.de).

We thank the Institute of Social Science Survey at Peking University for providing the data from its China Family Panel Studies (CFPS), which was funded by the university's 985 Program. We are also very grateful to the Center for Social Science Survey at Sun Yat-Sen University, Guangzhou, for providing the data from its China Labour-Force Dynamics Survey (CLDS, about which more information is available at http://css.sysu.edu.cn). The opinions expressed are the authors' alone. 


\section{Introduction}

Surprisingly little nationwide research exists on job satisfaction in China despite China offering an interesting case for job satisfaction analysis. In particular, Confucian-based work values such as hard work, endurance, collectivism, and personal networks (guanxi) mean that Chinese employees are expected to devote themselves to and take full responsibility for the job, work diligently, and generally align their values and goals with those of the organization (Lu et al., 2011). As a result, long work hours are common in China and may be the foundation for the unprecedented economic growth occurring since the 1979 economic reform (Smyth et al., 2013). Yet despite one of the longest work weeks in the world, Chinese worker health does not appear to be negatively affected (Nie et al., 2015), perhaps because a deeply rooted culture of long work hours "makes Chinese workers more resilient" than Western workers to its adverse effects (p. 225). Assumedly, this unique work ethic shapes job expectations, work motivation, and job satisfaction in ways not found in Western economies, meaning that what makes a job good in the West may not apply in China.

In addition to the distinct Chinese work ethic, gender roles in China are markedly different from those in the West. That is, although historically a patriarchal society with clear gender role demarcation (Ngo et al., 2014), China has comparatively high rates of female employment, with some evidence that Chinese women have higher job expectations than females in other countries (Loscocco and Bose, 1998). Nevertheless, as in many Western countries, Chinese women often experience structural barriers and unfair treatment (e.g., negative stereotypes, glass ceilings) that impair their future career development (Ngo et al., 2014).

This different gender ideology and China's unique Confucian-based work ethic make it questionable that the considerable Western research on job satisfaction determinants (Clark, 1997; Gazioglu and Tansel, 2006; Sousa-Poza and Sousa-Poza, 2000b) is generalizable to China, especially given that these determinants tend to differ across cultures and countries (Spector, 1997). The same is true for the research on how job satisfaction affects job turnover (Clark, 2001; Sousa-Poza and Sousa-Poza, 2007). Yet to date, there is little nationwide research on job satisfaction in China, probably because detailed job satisfaction data are not only limited but only recently subject to collection through nationwide surveys. In our analysis, therefore, we draw on two relatively new nationwide sources for such data: the 2012 China Labour-Force Dynamics Survey (CLDS) and the 2010-2012 China Family Panel Studies (CFPS).

Our contribution to the literature is threefold: First, we provide the most in-depth and up-to-date analysis of job satisfaction determinants in China, with a particular focus on gender differences. Given the enormous body of Western literature focused on gender differences in job satisfaction (Sousa-Poza and Sousa-Poza, 2000a), combined with the paradoxical observation that women tend to be more satisfied at work than men, we believe that this issue warrants investigation in a non-Western setting characterized 
by a unique gender ideology. Second, whereas analyses of the job satisfaction-labour turnover relation in China are lacking, many Western studies demonstrate a strong association between the two (e.g. Clark, 2001). Whether or not, and to what extent, this association also applies to a country with Confucian-based work values is unknown. We therefore use CFPS panel data to provide clear evidence of this relation. Third, by employing unique CLDS data that capture not only employee motives for working but the extent to which the job actually satisfies these motives, we directly assess what Chinese workers value or expect from a job and to what extent these expectations are currently being met.

\section{Data and Methods}

\subsection{Data and study sample}

Our analysis is based mainly on data from the CLDS, a large-scale, nationally representative, longitudinal survey administered by the Center for Social Survey at China's Sun YatSen University. First administered in 2012, a baseline survey encompasses 29 out of China's 31 provinces or autonomous regions (excluding Hainan and Tibet) (Hao and Liang, 2016). Given our study focus, we restrict our sample to employees aged 16-65, the common age range for the Chinese working-age population (cf., Perkins, 2015), for whom detailed information is available on demographics, household socioeconomics, and job satisfaction, which yields a final sample of 5,027 observations.

Our second dataset is the CFPS, administered by Peking University's Institute of Social Science Survey, which currently comprises three waves (2010, 2012, and 2014) covering 25 provinces or autonomous regions that account for $95 \%$ of the Chinese population (Xie and $\mathrm{Lu}, 2015$ ). In our sample, we include only respondents to the 2010 and 2012 surveys who were engaged in nonagricultural waged jobs in 2010, for a final sample of 4,452 employees aged 16-65. We exclude 2014 data from our analysis because only the 2010 survey contains detailed information on job satisfaction.

\subsection{Job satisfaction}

In line with Nielsen and Smyth (2008), we adopt a primarily global measure of job satisfaction based on a CLDS survey item asking respondents to rate their overall satisfaction with their current job on a 5-point scale from $1=$ very unsatisfactory to 5 = very satisfactory. The CFPS dataset asks for a similar evaluation, also rated on 5 -point scale from $1=$ very unsatisfied to $5=$ very satisfied. Such global measures of job satisfaction assume that employees are capable of balancing various job characteristics to reach an overall assessment of job satisfaction (Nielsen and Smyth, 2008). 


\subsection{Different work motives for the current versus ideal job}

To better understand what really makes a good job, we assess the perceived importance of different work motives for the current versus the ideal job, based on two CLDS questions that ask how important the current job is versus how important an ideal job would be in meeting the six specific needs: making a living, achieving inner peace, meeting more people, earning respect, satisfying (one's own) interest and realizing (one's own) potential. These responses, ranked on a 5-point scale from $1=$ very unimportant to $5=$ very important, allow us to assess the extent to which job expectations are being met.

\subsection{Job turnover}

Because the 2012 CFPS asks each employee in a nonagricultural waged job when they began this job, we can combine these responses with 2010 and 2012 employment status to generate a job change dummy equal to 1 if the individual left the 2010 job and 0 otherwise. More specifically, we define job change as the individual being employed in both 2010 and 2012 but with a 2012 tenure that began after 2010 .

\subsection{Explanatory variables}

We include variables for age, gender, education, marital status, type of household registration (hereafter, hukou), type of employer, weekly work hours, and monthly earnings. Gender is a dummy equal to 1 if the respondent is male and 0 otherwise. Education is measured on a 6-point scale of $1=$ illiterate, $2=$ primary school, $3=$ middle school, $4=$ high school, $5=$ vocational school, and $6=$ university or higher, which we then recode as a dummy with illiterate as the reference group. Marital status is measured on a 4-point scale of 1 = unmarried, 2 = married/living together, $3=$ divorced, and 4 = widowed, which we then recode as a dummy with unmarried as the reference group. Hukou is defined as a dummy equal to 1 if the respondent's household registration type was agricultural and 0 otherwise. Employer type is measured using a dummy equal to 1 if the employee was working at a stateowned enterprise (SOE) and 0 otherwise. Weekly work hours, monthly earnings (in yuan), and household size are also based on responses to corresponding survey items.

\subsection{Estimation strategies}

\subsubsection{Job satisfaction determinants}

We employ the 2012 CLDS to detect job satisfaction determinants by gender and estimate the following ordered probit model: 


$$
J S_{i}=\beta_{0}+\beta_{1} I_{i}+\beta_{2} H_{i}+\beta_{3} P_{i}+\varepsilon_{i},
$$

where $J S_{i}$ designates job satisfaction of individual $i, I_{i}$ is a vector of individual $i$ 's characteristics, $H_{i}$ denotes household size, $P_{i}$ is a vector of provincial dummies, and $\varepsilon_{i}$ is the error term.

\subsubsection{Assessing gender differences}

We use the 2012 CLDS data set to check gender differences attributable to demographic and socioeconomic characteristics. To identify which specific determinants account for the gender gap in job satisfaction, we employ a mean-based Blinder-Oaxaca (BO) decomposition (Blinder, 1973) that assumes a linear and additive nexus between job satisfaction and a given set of demographic and socioeconomic characteristics. In our case, the total difference in mean job satisfaction can be decomposed as follows:

$$
\bar{Y}^{F}-\bar{Y}^{M}=\left(\bar{X}^{F}-\bar{X}^{M}\right) \hat{\beta}^{M}+\bar{X}^{M}\left(\hat{\beta}^{F}-\hat{\beta}^{M}\right),
$$

where $\bar{X}^{i}$ is a vector of the averaged values of the independent variables and $\hat{\beta}^{i}$ is a vector of the coefficient estimates for males (denoted by $M$ ) and females (denoted by $F$ ). In Equation (2), the first (explained) term on the right indicates the contribution of a difference in the distribution of determinant $X$, while the second (unexplained) term refers to the part attributable to a difference in the determinants' effects (Jann, 2008). In keeping with the majority of previous research using decomposition (see, e.g., Sen, 2014), we focus on the explained terms and their disaggregated contribution for individual covariates, with a variable's contribution given by the average change in the function if that variable changes while all other variables remain the same.

\subsubsection{Analyzing turnover}

Given that the 2010-2012 CFPS data set is a panel setting, thereby facilitating us to examine the nexus between job satisfaction and job turnover. Therefore, following Sousa-Poza and Sousa-Poza (2007), we investigate the association between job satisfaction and individual job turnover by adopting the following probit model:

$$
L T_{i}=\alpha_{0}+\alpha_{1} J S_{i}+\alpha_{2} I_{i}+\alpha_{3} H_{i}+\alpha_{4} P_{i}+\delta_{i} .
$$

Where $L T_{i}$ is a dummy for individual $i$ 's labour turnover in $2012, J S_{i}$ denotes the job satisfaction of individual $i$ in 2010, and $I_{i}$ is a vector of individual $i$ 's characteristics in the 2010 wave, which is similar to those in Equation (1) but excludes the two job characteristics weekly work hours and monthly earnings because they are already captured by job satisfaction. $H_{i}$ denotes household size, $P_{i}$ is a vector of provincial dummies, and $\delta_{i}$ is the error term. 


\section{Results}

\subsection{Descriptive statistics}

As Appendix Table A1 shows, approximately $46 \%$ of the employees are either "satisfied" or "very satisfied" with their job, an outcome similar to Nielsen and Smyth's (2008) report that nearly $43 \%$ of Chinese employees are "quite" or "very satisfied". Another $47 \%$, however, are indifferent (neither satisfied nor dissatisfied), while about $7 \%$ of the workforce is explicitly dissatisfied. Although drawing direct comparisons with Western studies is difficult because the job satisfaction item is differently scaled, our results do suggest that Chinese workers are generally much less satisfied at work than workers in other parts of the world. Perhaps the most valid comparison is with Sousa-Poza and SousaPoza (2000b), whose 7-point scaling of International Social Survey Program data on job satisfaction reveals that $78 \%$ of workers across 21 countries are explicitly satisfied, $14 \%$ are indifferent, and $8 \%$ are explicitly dissatisfied.

Although Table 1 indicates that approximately $47 \%$ male employees versus $45 \%$ female employees report being at least satisfied with their jobs, we observe no statistically significant gender differences in job satisfaction. On the other hand, the average age for male workers is significantly higher than that for females (around 41 versus 38), males work significantly longer hours (45 hours/weeks vs. 40 hours/week), and, as is common in China (Nielsen and Smyth, 2008), males earn significantly higher monthly salaries $(2,196$ yuan vs. 1,666 yuan $)$. 
Table 1: Descriptive statistics by gender: CLDS 2012

\begin{tabular}{|c|c|c|c|}
\hline \multirow{2}{*}{ Variables } & Males & Females & Mean difference \\
\hline & (1) & (2) & (3) \\
\hline JS $(1=$ very unsatisfied to $5=$ very satisfied $)$ & 3.423 & 3.420 & -0.003 \\
\hline JS: very unsatisfactory & 0.011 & 0.010 & -0.001 \\
\hline JS: unsatisfactory & 0.068 & 0.059 & -0.009 \\
\hline JS: fair & 0.455 & 0.480 & 0.025 \\
\hline JS: satisfactory & 0.423 & 0.403 & -0.020 \\
\hline JS: very satisfactory & 0.044 & 0.048 & 0.004 \\
\hline Age & 40.668 & 37.766 & $-2.902^{* * *}$ \\
\hline Education: illiterate & 0.055 & 0.088 & $0.033^{* * *}$ \\
\hline Education: primary school & 0.215 & 0.192 & $-0.024^{* *}$ \\
\hline Education: middle school & 0.324 & 0.280 & $-0.044^{* * *}$ \\
\hline Education: high school & 0.162 & 0.116 & $-0.045^{* * *}$ \\
\hline Education: vocational school & 0.167 & 0.225 & $0.058^{* * *}$ \\
\hline Education: university or higher & 0.077 & 0.099 & $0.022^{* *}$ \\
\hline Marital status: unmarried & 0.147 & 0.130 & $-0.037^{* * *}$ \\
\hline Marital status: married/living together & 0.823 & 0.834 & $0.035^{* * * *}$ \\
\hline Marital status: divorced & 0.017 & 0.020 & $-0.005^{*}$ \\
\hline Marital status: widowed & 0.012 & 0.016 & $0.007^{* *}$ \\
\hline State-owned enterprises & 0.129 & 0.094 & $-0.033^{* * *}$ \\
\hline Monthly earnings (in yuan) & $2,196.317$ & $1,666.014$ & $-532.12^{* * *}$ \\
\hline Weekly work hours & 44.510 & 39.668 & $-4.016^{* * *}$ \\
\hline Family size & 3.325 & 3.375 & 0.004 \\
\hline Hukou (1 = agricultural, 0 = non-agricultural) & 0.561 & 0.638 & 0.007 \\
\hline Observation & 2,936 & 2,091 & - \\
\hline
\end{tabular}

Note: The mean values are based on the mean estimation adjusted by sampling weights. The significance of the mean difference is based on independent $t$-tests. JS $=$ job satisfaction. ${ }^{*} p<0.1,{ }^{* *} p<0.05,{ }^{* * *} p<0.01$

Source: CLDS 2012. 


\subsection{Expectations gap associated with different work motives}

To enhance our understanding of what really matters in a job, Figure 1 depicts the mean values of perceived importance of six different work motives for the current job and the ideal job. The corresponding figures for males and females are outlined in Appendix Figures A1 and A2, which reveal that the ranking of the average values for the perceived importance of motives for the current job is quite similar to that for the ideal job: making a living (4.106), achieving inner peace (3.629), earning respect (3.573), realizing potential (3.466), meeting more people (3.395), and satisfying interest (3.33). Based on these ratings, workers seem to be selecting themselves into jobs that match their values. Nevertheless, the figures also reveal significant discrepancies between the ideal and actual values, suggesting that although making a living (for example) is most important in both contexts, workers are not currently able to optimally fulfill this motive. This value gap thus implies an expectations gap: what workers experience is not what they expect from an ideal job. These expectations gaps are very large, ranging from 0.432 for satisfying interest to 0.118 for making a living. The general picture, therefore, is that, especially in terms of personal fulfillment (satisfying interest and realizing potential), Chinese workers expect more from their jobs.

Figure 1: Self-perceived importance for different purposes between the current job and the ideal job: (CLDS 2012), with the perceived importance of each purpose measured on a 5-point scale from 1 = very unimportant to 5 = very important.

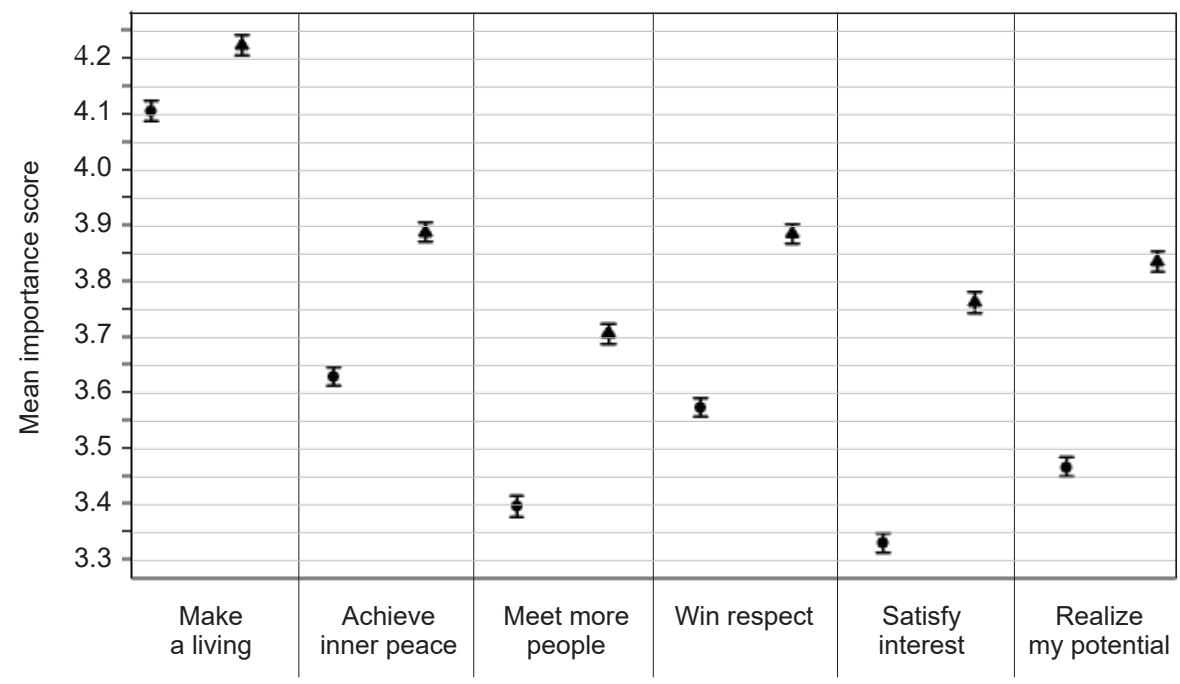

Each circle denotes individual current job and each triangle denotes individual ideal job.

Source: CLDS 2012. 
To shed more light on this expectations gap, we run an ordinary least square estimation with the gap as the dependent variable. We note that for most motives, the expectations gap declines with age, suggesting that workers probably adapt their expectations as they grow older. In most cases, the gap widens with higher levels of education, implying that this latter may go hand-in-hand with higher expectations. In general, the gap shrinks with income, possibly indicating that more attractive jobs are also better paid.

\subsection{Determinants of job satisfaction}

The results for job satisfaction determinants (Table 2) show a U-shaped association between age and job satisfaction among males, a common finding in the literature that is usually attributed to job expectations changing with age (Clark, 1996). That is, whereas job expectations (e.g., income, promotion) in younger years may be (too) high, giving rise to subsequent frustration and lower job satisfaction, as individuals age, their expectations adapt and job satisfaction rises again. An increased level of job satisfaction is also associated with a higher level of education (relative to illiteracy), especially for the full and male samples. Yet this finding is at odds with most Western research, which identifies a negative association between education and job satisfaction that Clark and Oswald (1996) interpret as the curse of high aspiration. This interpretation does not appear to hold in the Chinese setting, in which lower levels of job satisfaction are also linked to being unmarried or widowed, especially for the full and female samples (Columns 1 and 3). We do find a correlation between higher job satisfaction and higher monthly earnings, but as reported in several Western studies (see Sousa-Poza and Sousa-Poza, 2007), as well as Cheng et al. (2013) for China, job satisfaction tends to decrease with longer weekly work hours.

To further explore how the self-perceived importance of different motives for the current job is correlated with overall job satisfaction (see Table 3), we rank the relative importance of the six motives based on their marginal effects (Panel A). We identify satisfying interest and realizing potential as having the largest effect on job satisfaction in both the full and male samples. Women, however, consider realizing their potential and achieving inner peace more important than do men. We also note that earning respect, meeting more people, and making a living rank lower in both the male and female samples, which is at odds with our Figure 1 ranking of making a living as the most important motive for working. One possible explanation is the extremely strong association between job satisfaction and unfulfilled expectations, an assumption supported by the fact that in Table 3, the motives with the largest expectations gaps in Figure 1 are ranked highest. 
Table 2: Ordered probit estimates for job satisfaction determinants (CLDS 2012)

\begin{tabular}{|c|c|c|c|}
\hline & $\begin{array}{l}\text { All } \\
\text { (1) }\end{array}$ & $\begin{array}{c}\text { Males } \\
(2)\end{array}$ & $\begin{array}{c}\text { Females } \\
\text { (3) }\end{array}$ \\
\hline Age & $\begin{array}{c}-0.002 \\
(0.001)\end{array}$ & $\begin{array}{r}-0.003^{*} \\
(0.001)\end{array}$ & $\begin{array}{l}0.0003 \\
(0.002)\end{array}$ \\
\hline Age squared / 100 & $\begin{array}{l}0.004^{* *} \\
(0.002)\end{array}$ & $\begin{array}{l}0.005^{* * *} \\
(0.002)\end{array}$ & $\begin{array}{c}0.001 \\
(0.003)\end{array}$ \\
\hline Male & $\begin{array}{c}-0.006^{*} \\
(0.004)\end{array}$ & - & - \\
\hline Education: primary school & $\begin{array}{l}0.022^{* * *} \\
(0.007)\end{array}$ & $\begin{array}{c}0.025^{* *} \\
(0.010)\end{array}$ & $\begin{array}{c}0.011 \\
(0.011)\end{array}$ \\
\hline Education: middle school & $\begin{array}{l}0.022^{* * *} \\
(0.008)\end{array}$ & $\begin{array}{l}0.027^{* * *} \\
(0.010)\end{array}$ & $\begin{array}{c}0.009 \\
(0.012)\end{array}$ \\
\hline Education: high school & $\begin{array}{l}0.030^{* * * *} \\
(0.008)\end{array}$ & $\begin{array}{c}0.027^{* *} \\
(0.011)\end{array}$ & $\begin{array}{l}0.030^{* *} \\
(0.013)\end{array}$ \\
\hline Education: vocational school & $\begin{array}{l}0.041^{* * *} \\
(0.009)\end{array}$ & $\begin{array}{l}0.036^{* * *} \\
(0.012)\end{array}$ & $\begin{array}{l}0.041^{* * *} \\
(0.014)\end{array}$ \\
\hline Education: university or higher & $\begin{array}{l}0.036^{* * *} \\
(0.010)\end{array}$ & $\begin{array}{l}0.039^{* * *} \\
(0.014)\end{array}$ & $\begin{array}{c}0.024 \\
(0.015)\end{array}$ \\
\hline Marital status: married & $\begin{array}{c}0.004 \\
(0.006)\end{array}$ & $\begin{array}{c}0.010 \\
(0.008)\end{array}$ & $\begin{array}{r}-0.006 \\
(0.009)\end{array}$ \\
\hline Marital status: divorced & $\begin{array}{l}-0.010 \\
(0.013)\end{array}$ & $\begin{array}{c}-0.008 \\
(0.016)\end{array}$ & $\begin{array}{l}-0.013 \\
(0.018)\end{array}$ \\
\hline Marital status: widowed & $\begin{array}{c}-0.028^{*} \\
(0.016)\end{array}$ & $\begin{array}{c}0.002 \\
(0.020)\end{array}$ & $\begin{array}{c}-0.072^{* * * *} \\
(0.026)\end{array}$ \\
\hline SOES & $\begin{array}{l}-0.009 \\
(0.006)\end{array}$ & $\begin{array}{l}-0.008 \\
(0.007)\end{array}$ & $\begin{array}{l}-0.013 \\
(0.009)\end{array}$ \\
\hline Monthly earnings / 100 & $\begin{array}{l}0.001^{* * *} \\
(0.000)\end{array}$ & $\begin{array}{c}0.001^{* * *} \\
(0.000)\end{array}$ & $\begin{array}{c}0.001^{* * *} \\
(0.000)\end{array}$ \\
\hline Weekly work hours & $\begin{array}{c}-0.0002^{* *} \\
(0.000)\end{array}$ & $\begin{array}{c}-0.0001 \\
(0.000)\end{array}$ & $\begin{array}{c}-0.0002^{*} \\
(0.000)\end{array}$ \\
\hline Household size & $\begin{array}{l}0.004^{* * *} \\
(0.001)\end{array}$ & $\begin{array}{l}0.005^{* * *} \\
(0.002)\end{array}$ & $\begin{array}{c}0.002 \\
(0.002)\end{array}$ \\
\hline Hukou: agricultural & $\begin{array}{c}0.002 \\
(0.005)\end{array}$ & $\begin{array}{l}-0.001 \\
(0.006)\end{array}$ & $\begin{array}{c}0.004 \\
(0.008)\end{array}$ \\
\hline $\mathbf{N}$ & 5027 & 2936 & 2091 \\
\hline Pseudo $R^{2}$ & 0.024 & 0.031 & 0.027 \\
\hline
\end{tabular}

Note: The dependent variables are 5 -point measures of job satisfaction $(1=$ very unsatisfied to $5=$ very satisfied) and a job satisfaction dummy ( $1=$ satisfied/very satisfied, $0=$ otherwise). Marginal effects are calculated at the sample mean, and standard errors (in parentheses) are clustered at the community/ village level.

${ }^{*} p<0.1,{ }^{* *} p<0.05,{ }^{* * *} p<0.01$

Source: CLDS 2012. 
Table 3: Ordered probit estimates for the perceived importance for current job on overall job satisfaction (CLDS 2012)

\begin{tabular}{|c|c|c|c|c|c|c|}
\hline $\begin{array}{l}\text { Panel A: Perceived } \\
\text { importance }\end{array}$ & $\begin{array}{l}\text { All } \\
(1)\end{array}$ & $\begin{array}{c}\text { Rank } \\
(2)\end{array}$ & $\begin{array}{c}\text { Males } \\
(3)\end{array}$ & $\begin{array}{c}\text { Rank } \\
(4)\end{array}$ & $\begin{array}{c}\text { Females } \\
(5)\end{array}$ & $\begin{array}{c}\text { Rank } \\
(6)\end{array}$ \\
\hline Male & $\begin{array}{c}0.001 \\
(0.003)\end{array}$ & $\begin{array}{l}- \\
-\end{array}$ & $\begin{array}{l}- \\
-\end{array}$ & $\begin{array}{l}- \\
- \\
\end{array}$ & - & - \\
\hline Making a living & $\begin{array}{l}-0.008^{* *} \\
(0.004)\end{array}$ & $\begin{array}{l}6 \\
- \\
\end{array}$ & $\begin{array}{l}-0.001 \\
(0.005)\end{array}$ & $\begin{array}{l}6 \\
-\end{array}$ & $\begin{array}{l}-0.018^{* * *} \\
(0.006)\end{array}$ & $\begin{array}{l}6 \\
-\end{array}$ \\
\hline Achieving inner peace & $\begin{array}{l}0.023^{* * *} \\
(0.005)\end{array}$ & $\begin{array}{l}3 \\
-\end{array}$ & $\begin{array}{l}0.018^{* * *} \\
(0.006)\end{array}$ & $\begin{array}{l}3 \\
-\end{array}$ & $\begin{array}{l}0.031^{* * *} \\
(0.007)\end{array}$ & $\begin{array}{l}2 \\
-\end{array}$ \\
\hline Meeting more people & $\begin{array}{l}0.009^{* *} \\
(0.004)\end{array}$ & $\begin{array}{l}4 \\
- \\
\end{array}$ & $\begin{array}{c}0.007 \\
(0.005)\end{array}$ & $\begin{array}{l}4 \\
- \\
\end{array}$ & $\begin{array}{c}0.012^{*} \\
(0.006)\end{array}$ & $\begin{array}{l}4 \\
- \\
\end{array}$ \\
\hline Earning respect & $\begin{array}{c}0.005 \\
(0.004)\end{array}$ & $\begin{array}{l}5 \\
- \\
\end{array}$ & $\begin{array}{c}0.006 \\
(0.005)\end{array}$ & $\begin{array}{l}5 \\
- \\
\end{array}$ & $\begin{array}{c}0.004 \\
(0.006)\end{array}$ & $\begin{array}{l}5 \\
- \\
\end{array}$ \\
\hline Satisfying interest & $\begin{array}{l}0.026^{* * *} \\
(0.005)\end{array}$ & $\begin{array}{l}1 \\
-\end{array}$ & $\begin{array}{l}0.033^{* * *} \\
(0.006)\end{array}$ & $\begin{array}{l}1 \\
-\end{array}$ & $\begin{array}{c}0.015^{* *} \\
(0.007)\end{array}$ & $\begin{array}{l}3 \\
-\end{array}$ \\
\hline Realizing potential & $\begin{array}{l}0.024^{* * *} \\
(0.005)\end{array}$ & $\begin{array}{l}2 \\
-\end{array}$ & $\begin{array}{l}0.020^{* * *} \\
(0.006)\end{array}$ & $\begin{array}{l}2 \\
- \\
\end{array}$ & $\begin{array}{l}0.033^{* * *} \\
(0.008)\end{array}$ & $\begin{array}{l}1 \\
- \\
\end{array}$ \\
\hline $\mathbf{N}$ & 4,939 & - & 2,892 & - & 2,047 & - \\
\hline Pseudo $R^{2}$ & 0.050 & - & 0.054 & - & 0.056 & - \\
\hline Panel B: Expectation gaps & $\begin{array}{l}\text { All } \\
(1)\end{array}$ & $\begin{array}{c}\text { Rank } \\
(2)\end{array}$ & $\begin{array}{c}\text { Males } \\
(3)\end{array}$ & $\begin{array}{c}\text { Rank } \\
(4)\end{array}$ & $\begin{array}{c}\text { Females } \\
(5)\end{array}$ & $\begin{array}{c}\text { Rank } \\
\text { (6) }\end{array}$ \\
\hline Male & $\begin{array}{c}-0.0002 \\
(0.003)\end{array}$ & - & - & - & - & - \\
\hline Making a living & $\begin{array}{c}-0.0032 \\
(0.002)\end{array}$ & $\begin{array}{l}6 \\
- \\
-\end{array}$ & $\begin{array}{c}-0.0048^{*} \\
(0.003)\end{array}$ & $\begin{array}{l}4 \\
-\end{array}$ & $\begin{array}{c}-0.0014 \\
(0.003)\end{array}$ & $\begin{array}{l}6 \\
-\end{array}$ \\
\hline Achieving inner peace & $\begin{array}{c}-0.0079^{* * *} \\
(0.003)\end{array}$ & $\begin{array}{l}2 \\
- \\
\end{array}$ & $\begin{array}{c}-0.0061^{*} \\
(0.003)\end{array}$ & $\begin{array}{l}2 \\
- \\
\end{array}$ & $\begin{array}{c}-0.0111^{* * *} \\
(0.004)\end{array}$ & $\begin{array}{l}2 \\
- \\
\end{array}$ \\
\hline Meeting more people & $\begin{array}{c}-0.0043^{*} \\
(0.003)\end{array}$ & $\begin{array}{l}5 \\
-\end{array}$ & $\begin{array}{c}-0.0053^{*} \\
(0.003)\end{array}$ & $\begin{array}{l}3 \\
-\end{array}$ & $\begin{array}{c}-0.0025 \\
(0.004)\end{array}$ & $\begin{array}{l}5 \\
-\end{array}$ \\
\hline Earning respect & $\begin{array}{c}-0.0068^{* * *} \\
(0.002)\end{array}$ & $\begin{array}{l}3 \\
- \\
\end{array}$ & $\begin{array}{c}-0.0039 \\
(0.003)\end{array}$ & $\begin{array}{l}5 \\
- \\
\end{array}$ & $\begin{array}{c}-0.0112^{* * *} \\
(0.004)\end{array}$ & $\begin{array}{l}1 \\
- \\
\end{array}$ \\
\hline Satisfying interest & $\begin{array}{c}-0.0097^{* * *} \\
(0.002)\end{array}$ & $\begin{array}{l}1 \\
- \\
\end{array}$ & $\begin{array}{c}-0.0105^{* * *} \\
(0.003)\end{array}$ & $\begin{array}{l}1 \\
- \\
\end{array}$ & $\begin{array}{c}-0.0083^{* *} \\
(0.004)\end{array}$ & $\begin{array}{l}4 \\
- \\
\end{array}$ \\
\hline Realizing potential & $\begin{array}{c}-0.0045 \\
(0.003)\end{array}$ & $\begin{array}{l}4 \\
- \\
\end{array}$ & $\begin{array}{c}-0.0010 \\
(0.003)\end{array}$ & $\begin{array}{l}6 \\
- \\
\end{array}$ & $\begin{array}{c}-0.0106^{* *} \\
(0.005)\end{array}$ & $\begin{array}{l}3 \\
- \\
\end{array}$ \\
\hline $\mathbf{N}$ & 5,578 & - & 3,290 & - & 2,288 & - \\
\hline Pseudo $R^{2}$ & 0.024 & - & 0.023 & - & 0.033 & - \\
\hline
\end{tabular}

Note: The dependent variable is a 5 -point measure of job satisfaction (from $1=$ very unsatisfied to $5=$ very satisfied). In addition to dummies for gender and province, we also include controls for the perceived importance of work motives for the current job in Panel A and expectation gaps between the ideal job and the current job in Panel B. Marginal effects are calculated at the sample mean, and standard errors (in parentheses) are clustered at the community/village level.

${ }^{*} p<0.1,{ }^{* *} p<0.05,{ }^{* * *} p<0.01$

Source: CLDS 2012. 
Hence, to better account for the size of this expectations gap, we substitute it for motive importance and report the regression results in Panel B. We note that for all motives, the larger the expectations gap, the lower the job satisfaction level (with differing levels of significance). Nevertheless, for any given gap size, different motives have stronger effects on job satisfaction. We also observe certain gender differences, especially that men seem to value satisfying interest the most, whereas women primarily value earning respect. It should be stressed, however, that these gender differences are not large, so we can refute the differential job values hypothesis that men and women value job aspects differently and that objective reward measures (such as pay) may mean less to women than to men.

In fact, as indicated by the coefficient on making a living, in China neither male or female job satisfaction appears strongly affected by monetary considerations, which contrasts starkly with some Western studies identifying men as more income oriented than women (e.g., Clark, 2001). It should also be noted that on the face of it, this result seems at odds with the significant income coefficient in Table 2. This latter, however, may be capturing other job aspects besides income, such as how interesting the job is. Overall, therefore, and not surprisingly, making a living emerges as the most important motive, one satisfied by most employment offered, meaning no substantial expectations gap. Nevertheless, it is not this aspect that primarily drives job satisfaction but rather more intrinsic job attributes such as having an interesting job, a characteristic that Chinese workers really appear to value.

\subsection{Gender differences in job satisfaction}

Our failure to observe significant gender differences for China is especially interesting given the international evidence for the job satisfaction-gender paradox that women tend to be happier at work even when working conditions are bad enough to make even a nonsignificant gender difference paradoxical. We shed more light on this paradox using a BO decomposition analysis, which shows that although female employees have a slightly lower level of job satisfaction than males, the difference is statistically insignificant (see Table 4). On the other hand, our explained coefficient is significantly negative $(-0.045)$, indicating that, based on observables, women should actually have lower job satisfaction than men. Thus, the job satisfaction-gender paradox does hold for China. It is also worth noting that income has the largest (negative) decompositional coefficient of all the workplace characteristics, implying that women, given their much lower incomes, should be much less satisfied at work than they actually are. This finding is echoed in several Western studies (e.g., Sousa-Poza and Sousa-Poza, 2000a). 
Table 4: BO decomposition of job satisfaction determinants (CLDS 2012)

\begin{tabular}{|c|c|c|}
\hline & $\begin{array}{c}\text { Coefficients } \\
\text { (1) }\end{array}$ & $\begin{array}{c}\text { Contribution (\%) } \\
\text { (2) }\end{array}$ \\
\hline Females & $\begin{array}{l}3.420^{* * *} \\
(0.017)\end{array}$ & $\begin{array}{l}- \\
-\end{array}$ \\
\hline Males & $\begin{array}{l}3.423^{* * *} \\
(0.015)\end{array}$ & - \\
\hline Total difference & $\begin{array}{l}-0.003 \\
(0.023)\end{array}$ & - \\
\hline Explained & $\begin{array}{l}-0.045^{* * *} \\
(0.010)\end{array}$ & - \\
\hline Unexplained & $\begin{array}{l}0.042^{*} \\
(0.024) \\
\end{array}$ & $\begin{array}{l}- \\
- \\
\end{array}$ \\
\hline \multicolumn{3}{|c|}{ Explained part } \\
\hline Age & $\begin{array}{l}-0.032^{* * *} \\
(0.005)\end{array}$ & $\begin{array}{l}71 \\
- \\
\end{array}$ \\
\hline Education & $\begin{array}{c}0.002 \\
(0.004) \\
\end{array}$ & $\begin{array}{l}-4 \\
- \\
\end{array}$ \\
\hline Marital status & $\begin{array}{l}-0.001 \\
(0.001)\end{array}$ & $\begin{array}{l}2 \\
-\end{array}$ \\
\hline SOES & $\begin{array}{c}0.002 \\
(0.001)\end{array}$ & $\begin{array}{l}-4 \\
- \\
\end{array}$ \\
\hline Monthly earnings/100 & $\begin{array}{l}-0.027^{* * *} \\
(0.005)\end{array}$ & $\begin{array}{c}60 \\
- \\
\end{array}$ \\
\hline Weekly work hours & $\begin{array}{l}0.006^{* *} \\
(0.003)\end{array}$ & $\begin{array}{c}-13 \\
- \\
\end{array}$ \\
\hline Household size & $\begin{array}{c}0.001 \\
(0.001) \\
\end{array}$ & $\begin{array}{l}-2 \\
- \\
\end{array}$ \\
\hline Hukou: agricultural & $\begin{array}{l}-0.001 \\
(0.002) \\
\end{array}$ & $\begin{array}{r}2 \\
- \\
\end{array}$ \\
\hline Province & $\begin{array}{c}0.003 \\
(0.003) \\
\end{array}$ & $\begin{array}{l}-7 \\
- \\
\end{array}$ \\
\hline $\mathbf{N}$ & 5,027 & - \\
\hline
\end{tabular}

Note: The dependent variable is a 5 -point measure of job satisfaction (from $1=$ very unsatisfied to $5=$ very satisfied). Standard errors are in parentheses.

${ }^{*} p<0.1,{ }^{* *} p<0.05,{ }^{* *} p<0.01$

Source: CLDS 2012

\subsection{Job satisfaction and labour turnover}

Given the strong correlation in Western countries between low job satisfaction and job change (Clark, 2001), the large number of Chinese workers who are not explicitly satisfied (implying unmet job expectations) would suggest not only high turnover rates but a significant correlation between turnover and job satisfaction. 
Table 5: Probit estimates for overall job satisfaction and labour turnover (CFPS 2010-2012)

\begin{tabular}{|c|c|c|c|c|c|c|c|c|}
\hline & $\begin{array}{l}\text { All } \\
\text { (1) }\end{array}$ & $\begin{array}{l}\text { All } \\
\text { (2) }\end{array}$ & $\begin{array}{c}\text { Males } \\
\text { (3) }\end{array}$ & $\begin{array}{c}\text { Females } \\
\text { (4) }\end{array}$ & $\begin{array}{l}\text { All } \\
(5)\end{array}$ & $\begin{array}{l}\text { All } \\
(6)\end{array}$ & $\begin{array}{c}\text { Males } \\
\text { (7) }\end{array}$ & $\begin{array}{c}\text { Females } \\
\text { (8) }\end{array}$ \\
\hline Job satisfaction & $\begin{array}{l}-0.018 \\
(0.012)\end{array}$ & $\begin{array}{l}-0.023 \\
(0.018)\end{array}$ & $\begin{array}{l}-0.015 \\
(0.015)\end{array}$ & $\begin{array}{l}-0.021 \\
(0.023)\end{array}$ & $\begin{array}{c}-0.007 \\
(0.011)\end{array}$ & $\begin{array}{c}-0.009 \\
(0.017)\end{array}$ & $\begin{array}{c}-0.008 \\
(0.014)\end{array}$ & $\begin{array}{l}-0.014 \\
(0.018)\end{array}$ \\
\hline Male & $\begin{array}{l}- \\
-\end{array}$ & $\begin{array}{c}-0.006 \\
(0.013)\end{array}$ & $\begin{array}{l}- \\
-\end{array}$ & $\begin{array}{l}- \\
-\end{array}$ & $\begin{array}{l}-0.001 \\
(0.010)\end{array}$ & $\begin{array}{l}-0.003 \\
(0.012)\end{array}$ & $\begin{array}{l}- \\
-\end{array}$ & $\begin{array}{l}- \\
-\end{array}$ \\
\hline Job satisfaction X male & $\begin{array}{l}- \\
-\end{array}$ & $\begin{array}{c}0.007 \\
(0.023)\end{array}$ & $\begin{array}{l}- \\
-\end{array}$ & $\begin{array}{l}- \\
-\end{array}$ & $\begin{array}{l}- \\
-\end{array}$ & $\begin{array}{c}0.004 \\
(0.022)\end{array}$ & $\begin{array}{l}- \\
-\end{array}$ & $\begin{array}{l}- \\
-\end{array}$ \\
\hline Age & $\begin{array}{l}- \\
-\end{array}$ & $\begin{array}{l}- \\
-\end{array}$ & $\begin{array}{l}- \\
-\end{array}$ & $\begin{array}{l}- \\
-\end{array}$ & $\begin{array}{c}-0.013^{* * *} \\
(0.004)\end{array}$ & $\begin{array}{c}-0.012^{* * *} \\
(0.004)\end{array}$ & $\begin{array}{c}-0.015^{* * *} \\
(0.005)\end{array}$ & $\begin{array}{l}-0.009 \\
(0.008)\end{array}$ \\
\hline Age squared/100 & $\begin{array}{l}- \\
-\end{array}$ & $\begin{array}{l}- \\
-\end{array}$ & $\begin{array}{l}- \\
-\end{array}$ & $\begin{array}{l}- \\
-\end{array}$ & $\begin{array}{l}0.012^{* * *} \\
(0.004)\end{array}$ & $\begin{array}{l}0.012^{* * *} \\
(0.004)\end{array}$ & $\begin{array}{l}0.015^{* * *} \\
(0.006)\end{array}$ & $\begin{array}{c}0.007 \\
(0.010)\end{array}$ \\
\hline Education: primary school & $\begin{array}{l}- \\
-\end{array}$ & - & $\begin{array}{l}- \\
-\end{array}$ & $\begin{array}{l}- \\
-\end{array}$ & $\begin{array}{l}-0.007 \\
(0.023)\end{array}$ & $\begin{array}{l}-0.007 \\
(0.023)\end{array}$ & $\begin{array}{c}0.001 \\
(0.031)\end{array}$ & $\begin{array}{l}-0.028 \\
(0.040)\end{array}$ \\
\hline Education: middle school & $\begin{array}{l}- \\
-\end{array}$ & $\begin{array}{l}- \\
-\end{array}$ & $\begin{array}{l}- \\
-\end{array}$ & $\begin{array}{l}- \\
-\end{array}$ & $\begin{array}{c}-0.028 \\
(0.021)\end{array}$ & $\begin{array}{r}-0.028 \\
(0.021)\end{array}$ & $\begin{array}{r}-0.004 \\
(0.026)\end{array}$ & $\begin{array}{c}-0.076^{* *} \\
(0.036)\end{array}$ \\
\hline Education: high school & $\begin{array}{l}- \\
-\end{array}$ & - & $\begin{array}{l}- \\
-\end{array}$ & $\begin{array}{l}- \\
-\end{array}$ & $\begin{array}{l}-0.038 \\
(0.024)\end{array}$ & $\begin{array}{l}-0.038 \\
(0.024)\end{array}$ & $\begin{array}{r}-0.004 \\
(0.030)\end{array}$ & $\begin{array}{c}-0.108^{* * *} \\
(0.040)\end{array}$ \\
\hline $\begin{array}{l}\text { Education: vocational } \\
\text { school }\end{array}$ & $\begin{array}{l}- \\
-\end{array}$ & $\begin{array}{l}- \\
-\end{array}$ & $\begin{array}{l}- \\
-\end{array}$ & $\begin{array}{l}- \\
-\end{array}$ & $\begin{array}{l}-0.055^{* *} \\
(0.026)\end{array}$ & $\begin{array}{c}-0.055^{* *} \\
(0.026)\end{array}$ & $\begin{array}{l}-0.021 \\
(0.033)\end{array}$ & $\begin{array}{c}-0.122^{* * *} \\
(0.042)\end{array}$ \\
\hline $\begin{array}{l}\text { Education: university or } \\
\text { higher }\end{array}$ & $\begin{array}{l}- \\
-\end{array}$ & - & $\begin{array}{l}- \\
-\end{array}$ & $\begin{array}{l}- \\
-\end{array}$ & $\begin{array}{c}-0.093^{* * *} \\
(0.030)\end{array}$ & $\begin{array}{c}-0.093^{* * *} \\
(0.030)\end{array}$ & $\begin{array}{l}-0.068^{*} \\
(0.036)\end{array}$ & $\begin{array}{c}-0.159^{* * *} \\
(0.047)\end{array}$ \\
\hline $\begin{array}{l}\text { Marital status: married/ } \\
\text { living together }\end{array}$ & $\begin{array}{l}- \\
-\end{array}$ & - & $\begin{array}{l}- \\
-\end{array}$ & $\begin{array}{l}- \\
-\end{array}$ & $\begin{array}{l}-0.025 \\
(0.018)\end{array}$ & $\begin{array}{l}-0.025 \\
(0.018)\end{array}$ & $\begin{array}{l}-0.016 \\
(0.024)\end{array}$ & $\begin{array}{r}-0.052^{*} \\
(0.031)\end{array}$ \\
\hline Marital status: divorced & $\begin{array}{l}- \\
-\end{array}$ & $\begin{array}{l}- \\
-\end{array}$ & $\begin{array}{l}- \\
-\end{array}$ & $\begin{array}{l}- \\
-\end{array}$ & $\begin{array}{l}-0.040 \\
(0.050)\end{array}$ & $\begin{array}{l}-0.040 \\
(0.050)\end{array}$ & $\begin{array}{l}-0.010 \\
(0.062)\end{array}$ & $\begin{array}{c}-0.158^{* *} \\
(0.074)\end{array}$ \\
\hline Marital status: widowed & $\begin{array}{l}- \\
-\end{array}$ & $\begin{array}{l}- \\
-\end{array}$ & $\begin{array}{l}- \\
-\end{array}$ & $\begin{array}{l}- \\
-\end{array}$ & $\begin{array}{c}0.018 \\
(0.064)\end{array}$ & $\begin{array}{c}0.018 \\
(0.063)\end{array}$ & $\begin{array}{c}0.026 \\
(0.069)\end{array}$ & $\begin{array}{l}-0.029 \\
(0.095)\end{array}$ \\
\hline SOES & $\begin{array}{l}- \\
-\end{array}$ & $\begin{array}{l}- \\
-\end{array}$ & $\begin{array}{l}- \\
-\end{array}$ & $\begin{array}{l}- \\
-\end{array}$ & $\begin{array}{c}-0.046^{* * *} \\
(0.018)\end{array}$ & $\begin{array}{c}-0.046^{* * *} \\
(0.018)\end{array}$ & $\begin{array}{c}-0.053^{* *} \\
(0.023)\end{array}$ & $\begin{array}{l}-0.023 \\
(0.030)\end{array}$ \\
\hline Household size & $\begin{array}{l}- \\
-\end{array}$ & $\begin{array}{l}- \\
-\end{array}$ & $\begin{array}{l}- \\
-\end{array}$ & $\begin{array}{l}- \\
-\end{array}$ & $\begin{array}{c}0.000 \\
(0.003)\end{array}$ & $\begin{array}{c}0.000 \\
(0.003)\end{array}$ & $\begin{array}{c}0.002 \\
(0.004)\end{array}$ & $\begin{array}{l}-0.002 \\
(0.005)\end{array}$ \\
\hline Urban & $\begin{array}{l}- \\
-\end{array}$ & $\begin{array}{l}- \\
-\end{array}$ & $\begin{array}{l}- \\
-\end{array}$ & $\begin{array}{l}- \\
-\end{array}$ & $\begin{array}{l}-0.015 \\
(0.013)\end{array}$ & $\begin{array}{l}-0.015 \\
(0.013)\end{array}$ & $\begin{array}{r}-0.021 \\
(0.015)\end{array}$ & $\begin{array}{l}-0.003 \\
(0.022)\end{array}$ \\
\hline $\mathrm{N}$ & 4,452 & 4,452 & 2,796 & 2,151 & 4,452 & 4,452 & 2,796 & 2,151 \\
\hline Pseudo $R^{2}$ & 0.002 & 0.002 & 0.001 & 0.001 & 0.086 & 0.086 & 0.090 & 0.102 \\
\hline
\end{tabular}

Note: The dependent variable is a job turnover dummy $(1=$ movers, $0=$ stayers $)$. Marginal effects are calculated at the sample mean, and standard errors (in parentheses) are clustered at the community/ village level.

${ }^{*} p<0.1,{ }^{* *} p<0.05,{ }^{* * *} p<0.01$

Source: CFPS 2010-2012. 
However, when we regress turnover using different subsamples and specifications, the job satisfaction coefficient, although negative, is never significant (see Table 5). Our explanation for this unique finding, albeit speculative, is that the Chinese Confucian-based work ethic, which stipulates endurance, loyalty, and guanxi, may inhibit the inclination to change jobs when dissatisfied. We also note that job-to-job mobility is significantly lower than in most Western countries, only about 7\% between 2010 and 2012 compared with a 1-year EU job mobility rate in the 15-18\% range between 1995 and 2005 (Recchi, 2009).

\section{Discussion and Conclusions}

Although different item coding prevents a direct comparison with Western findings, our results do appear to indicate that job satisfaction levels are generally much lower in China than in the West. Only $46 \%$ of the employees reported being explicitly satisfied with their jobs. Men and women have very similar levels of job satisfaction, yet, based on observables, women should have a lower level of job satisfaction relative to men. At the same time, even though low income and long work hours may contribute to lower job satisfaction levels, discontent seems primarily driven by significant divergence in what workers consider important in a job and what they actually experience, an expectations gap that is particularly pronounced among younger employees. For most Chinese workers, the leading motive for work is making a living, a goal that most jobs fulfill, meaning a relatively small expectations gap. The fact that this gap seem to have no strong effect on job satisfaction implies that more intrinsic job characteristics matter more than monetary aspects. In fact, the largest expectation gaps are for satisfying interest and achieving inner peace, both strongly associated with lower job satisfaction. Also in stark contrast to Western research (e.g., Clark, 2001), we find no association between overall job satisfaction and labour turnover.

Overall, our results provide limited evidence that job satisfaction is a predictor for labour turnover in China. At least three underlying and related explanations for this observation come to mind: First, as highlighted by Tian-Foreman (2009), labour turnover is strongly influenced by the condition of the labour market, chances of obtaining other employment, and financial responsibilities. Furthermore, as emphasized by Knight and Yueh (2004), even after the reform of SOEs in the late 1980s and 1990s and the recent proliferation of non-standard employment in China, which allows workers more freedom to move from one employer to another, voluntary job mobility remains constrained by the employer-specific provision of social welfare services such as pensions, medical care and housing.

Second, several studies have confirmed that China has low job mobility rates (see, Knight and Yueh, 2004; Li, 2013). For instance, $\operatorname{Li}(2013)$ shows that the average rate of job mobility in urban China is merely $7.7 \%$ during the period of 1997-2008 - a result which 
corresponds closely to the 7\% job-to-job rate observed in our sample of Chinese workers. Such a job mobility rate is much lower than those encountered in western countries: for example, Skora et al. (2013), using panel data from two waves (2007 and 2011/2012) of the study "Job Mobilities and Family Lives in Europe - Modern Mobile Living and its Relation to Quality of Life", show that job mobility rates in Germany, France, Spain and Switzerland are $17.5 \%, 17.3 \%, 12.6 \%$ and $13.1 \%$, respectively. Such low mobility rates (whatever their cause) can make it more difficult to observe a significant effect of job satisfaction on labour turnover.

Finally, Wong et al. (2001) show that whereas job satisfaction has no direct effect on turnover intentions, organizational commitment does. This finding may suggest that traditional Chinese work values like endurance, organizational loyalty, and guanxi have a crucial effect on Chinese employees' work-related attitudes and behaviours (Lu et al., 2011). Such typical Chinese work values may also attenuate the effect of job satisfaction on labour turnover. Thus, summing-up, labour market and institutional constraints, low mobility rates, and typical Chinese work values may all have an attenuating effect of job satisfaction on labour turnover. 


\section{Appendix}

Table A1: Descriptive statistics (CLDS 2012)

\begin{tabular}{|c|c|c|c|c|}
\hline Variable & Mean & Std. Err. & & $\mathrm{Cl}$ \\
\hline JS & 3.422 & 0.011 & 3.400 & 3.443 \\
\hline JS: very unsatisfactory & 0.010 & 0.001 & 0.007 & 0.013 \\
\hline JS: unsatisfactory & 0.064 & 0.004 & 0.057 & 0.071 \\
\hline JS: fair & 0.465 & 0.008 & 0.450 & 0.480 \\
\hline JS: satisfactory & 0.415 & 0.008 & 0.400 & 0.430 \\
\hline JS: very satisfactory & 0.046 & 0.003 & 0.040 & 0.052 \\
\hline Age & 39.481 & 0.174 & 39.139 & 39.822 \\
\hline Male & 0.591 & 0.008 & 0.576 & 0.606 \\
\hline Education: illiterate & 0.068 & 0.004 & 0.061 & 0.076 \\
\hline Education: primary school & 0.206 & 0.006 & 0.193 & 0.218 \\
\hline Education: middle school & 0.306 & 0.007 & 0.292 & 0.320 \\
\hline Education: high school & 0.143 & 0.005 & 0.133 & 0.154 \\
\hline Education: vocational school & 0.191 & 0.006 & 0.179 & 0.203 \\
\hline Education: university or higher & 0.086 & 0.004 & 0.078 & 0.095 \\
\hline Marital status: unmarried & 0.140 & 0.005 & 0.130 & 0.151 \\
\hline Marital status: married/living together & 0.827 & 0.006 & 0.816 & 0.839 \\
\hline Marital status: divorced & 0.018 & 0.002 & 0.014 & 0.023 \\
\hline Marital status: widowed & 0.014 & 0.002 & 0.010 & 0.018 \\
\hline SOES & 0.114 & 0.005 & 0.105 & 0.124 \\
\hline Monthly earnings (in yuan) & $1,979.392$ & 22.807 & $1,934.681$ & $2,024.103$ \\
\hline Weekly work hours & 42.529 & 0.366 & 41.811 & 43.247 \\
\hline Family size & 3.345 & 0.020 & 3.305 & 3.386 \\
\hline Hukou (1 = agricultural, 0 = non-agricultural) & 0.606 & 0.007 & 0.592 & 0.621 \\
\hline Observation & 5,027 & - & - & - \\
\hline
\end{tabular}

Note: The mean values are based on the mean estimation adjusted by sampling weights.

$J S=$ job satisfaction; Std. Err. = standard error; $\mathrm{Cl}=$ confidence intervals.

Source: CLDS 2012. 
Figure A1: Perceived importance of the six different motives for the current versus the ideal job among males, measured on a 5 -point scale from $1=$ very unimportant to $5=$ very important (CLDS 2012)

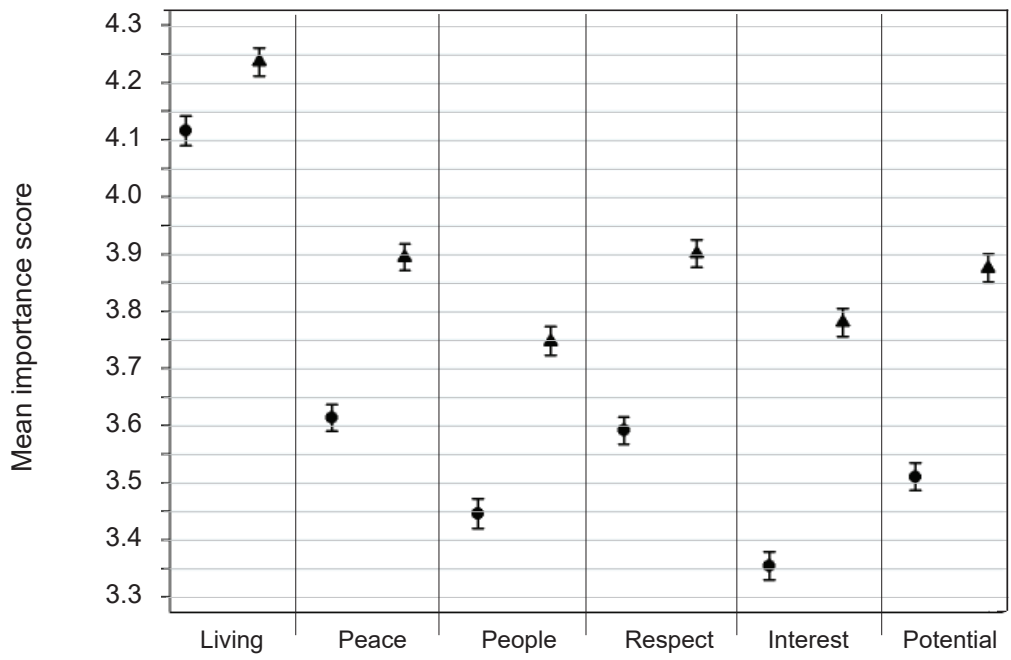

Each circle denotes individual current job and each triangle denotes individual ideal job.

Source: CLDS 2012.

Figure A2: Perceived importance of the six different motives for the current versus the ideal job among females, measured on a 5 -point scale from $1=$ very unimportant to $5=$ very important (CLDS 2012)

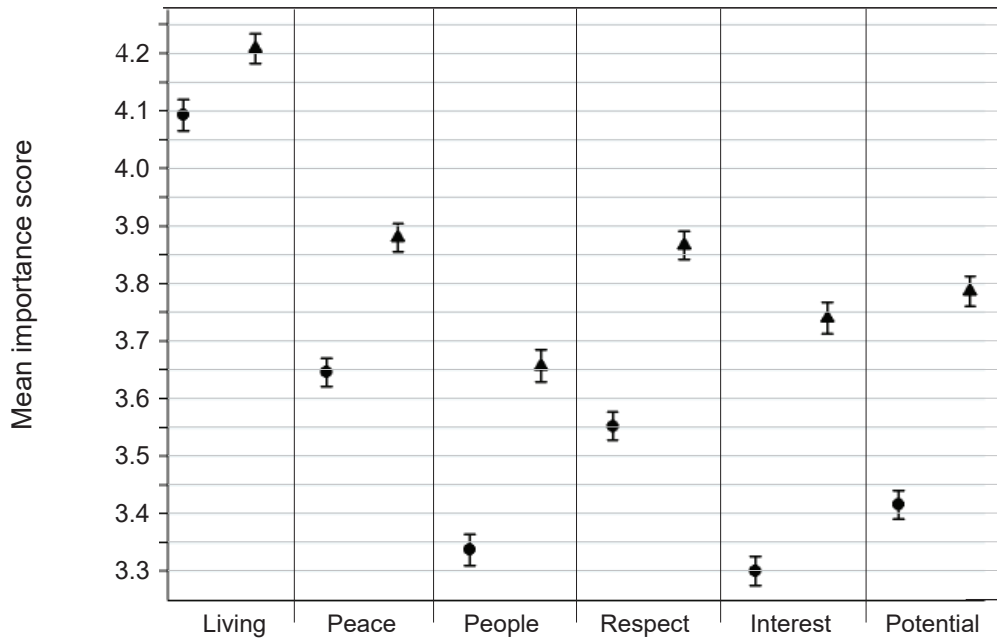

Each circle denotes individual current job and each triangle denotes individual ideal job.

Source: CLDS 2012. 


\section{References}

Blinder, A. S. (1973). Wage Discrimination: Reduced form and Structural Estimates. The Journal of Human Resources, 8(4), 436-455, https://doi.org/10.2307/144855

Cheng, Z., Wang, H., Smyth, R. (2013). Happiness and Job Satisfaction in Urban China:

A Comparative Study of Two Generations of Migrants and Urban Locals. Urban Studies, 51(10), 2160-2184, https://doi.org/10.1177/0042098013506042

Clark, A. E. (1996). Job satisfaction in Britain. British Journal of Industrial Relations, 34(2), 189-217, https://doi.org/10.1111/j.1467-8543.1996.tb00648.x

Clark, A. E. (1997). Job Satisfaction and Gender: Why are Women so Happy at Work? Labour Economics, 4(4), 341-372, https://doi.org/10.1016/s0927-5371(97)00010-9

Clark, A. E. (2001). What Really Matters in a Job? Hedonic Measurement Using Quit Data. Labour Economics, 8(2), 223-242, https://doi.org/10.1016/s0927-5371(01)00031-8

Clark, A. E. (2015). What Makes a Good Job? Job Quality and Job Satisfaction. IZA World of Labour, 215, 1-10, https://doi.org/10.15185/izawol.215

Clark, A. E., Oswald, A. J. (1996). Satisfaction and Comparison Income. Journal of Public Economics, 61(3), 359-381, https://doi.org/10.1016/0047-2727(95)01564-7

Gazioglu, S., Tansel, A. (2006). Job Satisfaction in Britain: Individual and Job Related Factors. Applied Economics, 38(10), 1163-1171, https://doi.org/10.1080/00036840500392987

Hao, L., Liang, Y. (2016). The Spatial and Career Mobility of China's Urban and Rural Labour Force. Management and Organization Review, 12(1), 135-158, https://doi.org/10.1017/ mor.2015.35

Jann, B. (2008). The Blinder-Oaxaca Decomposition for Linear Regression Models. Stata Journal, 8(4), 453-479, https://doi.org/10.1177/1536867x0800800401

Knight, J., Yueh, L. (2004). Job Mobility of Residents and Migrants in urban China. Journal of Comparative Economics, 32(4), 637-660, https://doi.org/10.1016/j.jce.2004.07.004

Li, J. (2013). Job Mobility in Postreform urban China. Chinese Sociological Review, 45(4), 81-109, https://doi.org/10.2753/csa2162-0555450404

Loscocco, K. A., Bose, C. E. (1998). Gender and Job Satisfaction in Urban China: The Early PostMao Period. Social Science Quarterly, 79(1), 91-109.

Lu, L., Kao, S. F., Siu, O. L., Lu, C. Q. (2011). Work Stress, Chinese Work Values, and Work Wellbeing in the Greater China. The Journal of Social Psychology, 151(6), 767-783, https://doi.org/10.1080/00224545.2010.538760

Ngo, H. Y., Foley, S., Ji, M. S., Loi, R. (2014). Work Satisfaction of Chinese Employees: A Social Exchange and Gender-based View. Social Indicators Research, 116(2), 457-473, https://doi.org/10.1007/s11205-013-0290-2

Nie, P., Otterbach, S., Sousa-Poza, A. (2015). Long Work Hours and Health in China. China Economic Review, 33, 212-229, https://doi.org/10.1016/j.chieco.2015.02.004

Nielsen, I., Smyth, R. (2008). Job Satisfaction and Response to Incentives Among China's Urban Workforce. The Journal of Socio-Economics, 37(5), 1921-1936, https://doi. org/10.1016/j.socec.2008.02.008 
Perkins, D. H. (2015). The Economic Transformation of China. Massachusetts, USA: World Scientific Publishing Co. Pte. Ltd.

Recchi, E. (2009). Chapter 4: The Social Mobility of Mobile Europeans, in Recchi, E., Favell, A., eds., Pioneers of European Integration: Citizenship and Mobility in the EU. Cheltenham, UK: Edward Elgar Publishing Limited,

Sen, B. (2014). Using the Oaxaca-Blinder Decomposition as an Empirical Tool to Analyze Racial Disparities in Obesity. Obesity, 22(7), 1750-1755, https://doi.org/10.1002/ oby. 20755

Skora, T., Rüger, H., Schneider, N. F. (2013). Job Mobilities and Family Lives in Europe. Documentation of the Panel Dataset. Federal Institute for Population Research. Wiesbaden BiB Daten- und Methodenberichte 1/2013.

Smyth, R., Qian, X., Nielsen, I., Kaempfer, I. (2013). Working Hours in Supply Chain Chinese and Thai Factories: Evidence from the Fair Labour Association's 'Soccer Project'. British Journal of Industrial Relations, 51(2), 382-408, https://doi.org/10.1111/j.1467-8543.2011.00881.x

Sousa-Poza, A., Sousa-Poza, A. A. (2000a). Taking another Look at the Gender/Job-satisfaction Paradox. Kyklos, 53(2), 135-152, https://doi.org/10.1111/1467-6435.00114

Sousa-Poza, A., Sousa-Poza, A. A. (2000b). Well-being at work: A cross-national Analysis of the Levels and Determinants of Job Satisfaction. The Journal of Socio-Economics, 29(6), 517-538, https://doi.org/10.1016/s1053-5357(00)00085-8

Sousa-Poza, A., Sousa-Poza, A. A. (2007). The Effect of Job Satisfaction on Labour Turnover by Gender: An Analysis for Switzerland. The Journal of Socio-Economics, 36(6), 895-913, https://doi.org/10.1016/j.socec.2007.01.022

Spector, P. E. (1997). Job Satisfaction: Application, Assessment, Causes and Consequences. California: Sage Publications, http://doi.org/10.4135/9781452231549

Tian-Foreman, W. (2009). Job Satisfaction and Turnover in the Chinese Retail Industry. Chinese Management Studies, 3(4), 356-378, https://doi.org/10.1108/17506140911007503

Wong, C. S., Wong, Y. T., Hui, C., Law, K. S. (2001). The Significant Role of Chinese Employees' Organizational Commitment: Implications for Managing Employees in Chinese Societies. Journal of World Business, 36(3), 326-340, https://doi.org/10.1016/ s1090-9516(01)00058-x

Xie, Y., Lu, P. (2015). The Sampling Design of the China Family Panel Studies (CFPS). Chinese Journal of Sociology, 1(4), 471-484, https://doi.org/10.1177/2057150x15614535 